\title{
Fear Culture II
}

\author{
Miss Nevin MERT \\ Atilim University, Psychology-Public Relations \& Advertisement, Ankara, Turkey \\ Email: nevin_mert@hotmail.com
}

Accepted: January 5, 2012 Published: March 23, 2012

Doi:10.5296/ijld.v2i2.1547ＵRL: http://dx.doi.org/10.5296/ijld.v2i2.1547

\begin{abstract}
What is fear? Is it something innate or learned or ever something very complex to understand? Fear takes an important place in human lives, and it also has different definitions. Even though we experience and use the concept such as fear, we do not exactly know what fear ever means. However, why do we experience fear? So, this research is done in order to understand the concept of fear in more detailed. The purpose of the study is to see what kind of fear types do we have, and where fear ever comes from. In the research we explain fear in terms of developmental, humanistic, behaviourist, social aspects and also in terms of public relations. Since this study is done in Turkey, the issues are taken according to Turkish culture as well. However, the aim of the study is to make observation on the issue whether Turkey experiences fear or not. On the other words, whether Turkey is a "fear culture" in its own. In order to observe it (whether Turkey is a fear culture or not), we used the cultural aspects of the particular regions such as the observations of West and East parts of the country. The findings showed that even though the fear does exist, the types and reasons of fear show huge differences.
\end{abstract}

Keywords: Fear; Fear Types; Turkey as a Fear Culture

As it is widely known, everybody lives with some expectations. However, these expectations might show some changes parallel to situations. In every part of our lives, we come across with different problems. Therefore, these problems always affect us not in a way we expect. At that point, fear appears. Observing its first capital letters, the case such as "False Evidence Appearing Real" could be found. However, it's one of the worst problems humans are facing since centuries. It makes people do weird things. It makes people feel insecure, uncertain and anxious, it can even destroy relationships. So, it is one such emotion that plays an important part in our lives and is pre-programmed into all animals and people as an instinctual response to 
potential danger ${ }^{1}$. When a person experiences fear, the amygdala and the hypothalamus (the certain areas in the brain) are immediately activated and appear to control the first physical response to fear. Chemicals such as adrenaline and the stress hormone that is cortisol are released into the blood stream causing certain physical reactions such as rapid heart rate, increased blood pressure, tightening of muscles, sharpened or redirected senses, dilation of the pupils (to let in more light), increased sweating ${ }^{2}$. The aim of this article is to find out the causes and results of fear in our country and whether our country experiences the "fear culture" from developmental, humanistic, behaviourist, social aspects and in terms of public relations.

There are so many explanations of fear, however, it is important to mention that fear and phobia are closely related with each other. So, to explain fear, it is a good idea to look at the types of phobias such as Algophobia, a fear of pain; Pyrophobia, a fear of fire or Hydrophobia, a fear of water (for more information look at Appendix).

Approaching from the Developmental Psychology aspect, the first thing that is going to describe is why children experience fear. In general there are two types of fears ${ }^{3}$. The first one is instinctive fear and the second one is learned fear. Children until 4 years-old experience the instinctive fears. When the baby hears a loud voice, s/he leaps, because at that moment s/he experiences fear (the first type of fear). These fears could also be fanciful like seeing monsters that are going to eat them or the similar shapes. There is also the second type of fear which is the learned one. This fear is learned either from the parents, or from the environment, or from television. For instance, the mother of the child screams when she sees a white toy, and the child generalizes it as if all white toys are harmful and begins to cry. The fears learned from friends are also sourced by parents. For example, the parents of a child can say "If you do not sleep, the monsters will come to eat you". So, the child hearing this sentence will share it with his/her friends and as a result his/her friends will also think about it and will experience the same fear. However, there are some fears which do not change during the life-span. In general, phobias such as Algophobia (a fear of pain), Pyrophobia (a fear of fire) are more permanent. Conversely, the fears experienced by child (fear of monsters) are more temporary because they disappear after a certain time. After looking at these types of phobias, it is clear that people at every moment of their lives may experience fear which can affect them.

Approaching from Psychosexual Developmental aspect, S. Freud mentioned the basics of "inborn" fears. According to him (Benjamin B. Lacey, An Introduction, NY: McGraw-Hill, 469-471), there are five stages in the Psychosexual Development. The first stage which includes the phallic stage is important for us at this point because it includes the Oedipus complex describing inborn fears. In this stage (3 to 6 Years) gratification is focused on the genitals, and where the Oedipus complex exists. According to Freud, the unconscious wish of all male children to kill their fathers and sexually possess their mothers is the description of the Oedipus complex. However, they cannot do this because of the castration anxiety (the fear of a

\footnotetext{
${ }^{1} \mathrm{http} / / /$ www.nativeremedies.com/ailment/overcoming-fears-info.html

${ }^{2}$ http://nativeremedies.com/ailment/overcoming-fears-info.html

${ }^{3}$ Elif GÜRSOY, the psychologist of human development.
} 
young boy that his father will punish his sexual desire for his mother by removing his genitals). Another point is that experiencing fear generally goes parallel with the people age. Nevertheless, to guess the time when the child is going to experience fear is too hard because there are past experiences and current psycho-physiological and environmental conditions as causes of fear. According to the research done between children in rural regions, $\% 75$ of fear contains the existence of animals ${ }^{4}$. However, in West countries (in urban regions), there is a survey done between children of 9 years-old and \%40 of fear cause due to bodily harm, robbery, child thieves, death and animal existence ${ }^{5}$. As it is seen, when the animal existence takes the first place in rural regions, in urban regions it could take the last place.

In terms of Personality Development, according to Erikson (Benjamin B. Lacey, An Introduction, NY: McGraw-Hill, pp. 326), there are eight stages and after observing each of them, we can say that every stage has experienced fear. In each stage something is in contrast with something. For example, in the first stage that is basic trust versus mistrust it is seen to experience fear, because here, a person learns to feel comfortable and trust parents' care. However, opposite to this, due to the mistrust, a person may develop a deep mistrust to the world that is perceived to be unsafe. So, as it is seen, a person experiences his first fears ${ }^{6}$.

From Cognitive Developmental aspect, Piaget's perspective ${ }^{7}$, for improvement of child's cognitive and linguistic conceptions, there are four stages (sensorimotor, preoperational, concrete operational, and formal operational) which should be passing though. The human being is strongly affected by the society and the "self" is also formed by it. So, since families are growing up their children, they have a big responsibility. If the child's family is leaded by the dogmatic system, there is a probability of a child being raised in the same way. For a child, there is a critical period of developing the cognitive concept. So, the leaders are aware of it and by having connections with their families, they also affect the children. Though it will be easier for the leaders to grow up the children they want to see in the future. Another point is that, our century experiences anti-democratic system. In other words, families leading their children acts shape these children and their actions. However, when they themselves do the same actions they find some excuses such as telling that they are grownups and in a way hide their own feelings. After taking all these facts into consideration, we can see that in every period people has a tendency to be affected by the leaders. All these affections are the causes of fear.

\footnotetext{
${ }^{4}$ Yavuzer, Çocuk Psikolojisi, s. 39

${ }_{6}^{5}$ Mary J. Gander, Harry W. Gardiner, Çocuk ve Ergen Gelişimi, çev. ed. Bekir Onur, Ankara 1993, s. 381

${ }^{6}$ Benjamin B. Lahey, Psychology An Introduction, NY: McGraw- Hill, 9th Edition, page 379

${ }^{7}$ Diane E. Papalia, Sally Wendkos Olds, \& Ruth Duskin Feldman, Human Development, $10^{\text {th }}$ Edition, NY: McGraw-Hill, pages 248, 487.
} 


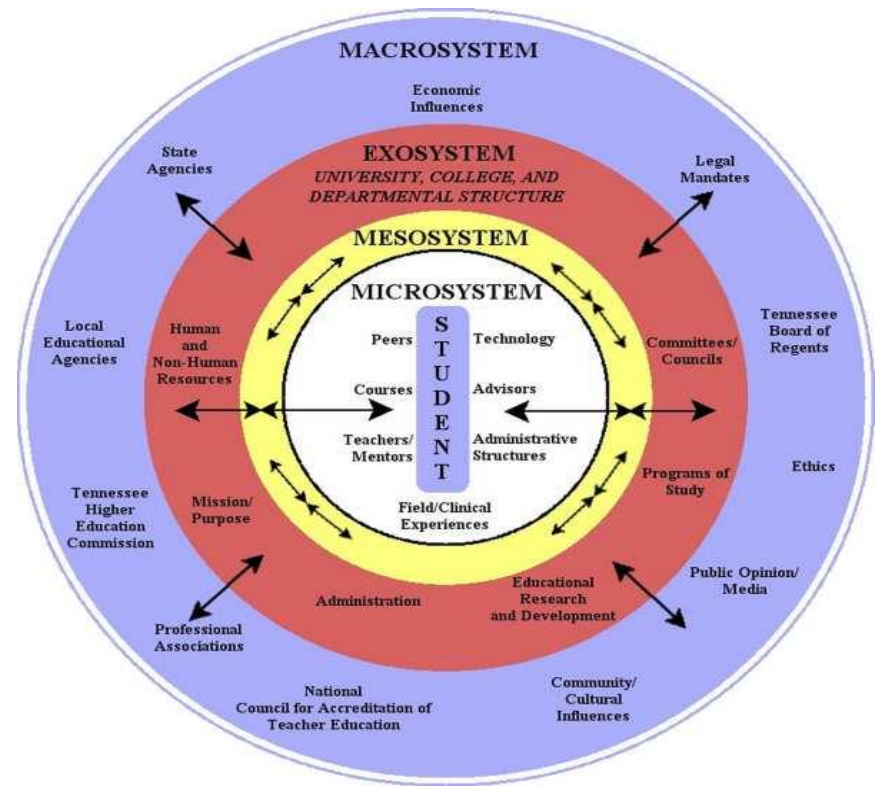

From Human Developmental aspect, the approach made by Bronfenbrenner, there are five interlocking contextual systems, from the most intimate to the broadest: the micro system, mesosystem, ecosystem, macro system and chronosystem. According to Bronfenbrenner (Diane E. Papalia, Sally Wendkos Olds, \& Ruth Duskin Feldman, Human Development, $10^{\text {th }}$ ed., page 41-42) ,the first four systems are like hollow cylinders that fit inside one another, encasing the developing person. The fifth, the chronosystem, adds the dimension of time. As it is seen in figure, the borderers between the systems are fluid; although we separate the various levels of influence for purposes of illustration, in reality they continually interact. As in Maslow's hierarchy of need, lack of one "relation" may cause to huge problems. All these problems cause stress and as a result of that fear appears.

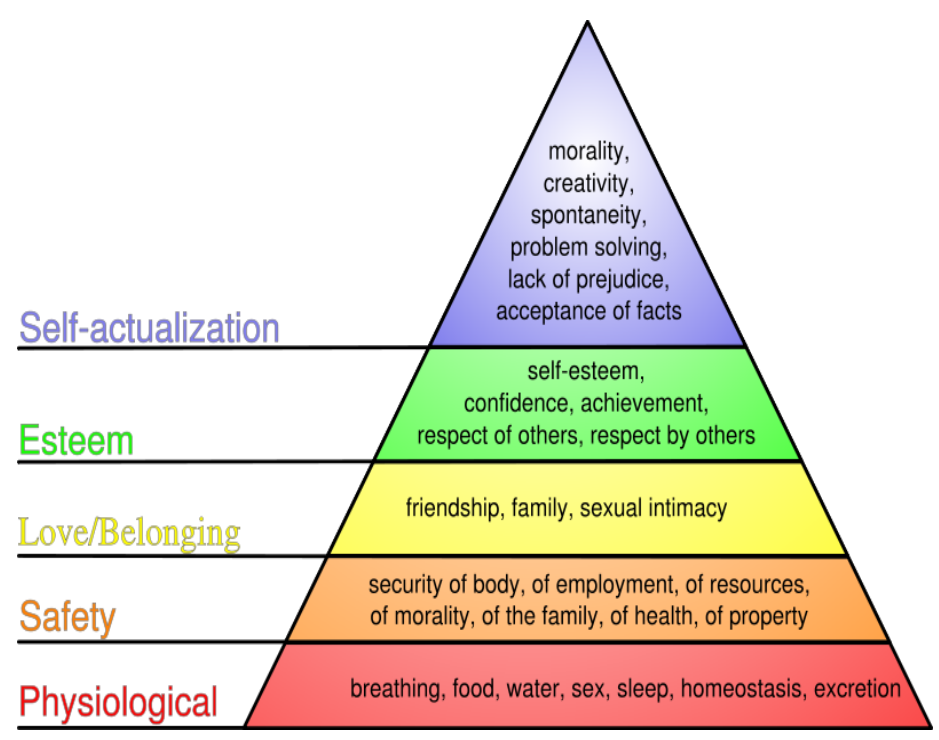




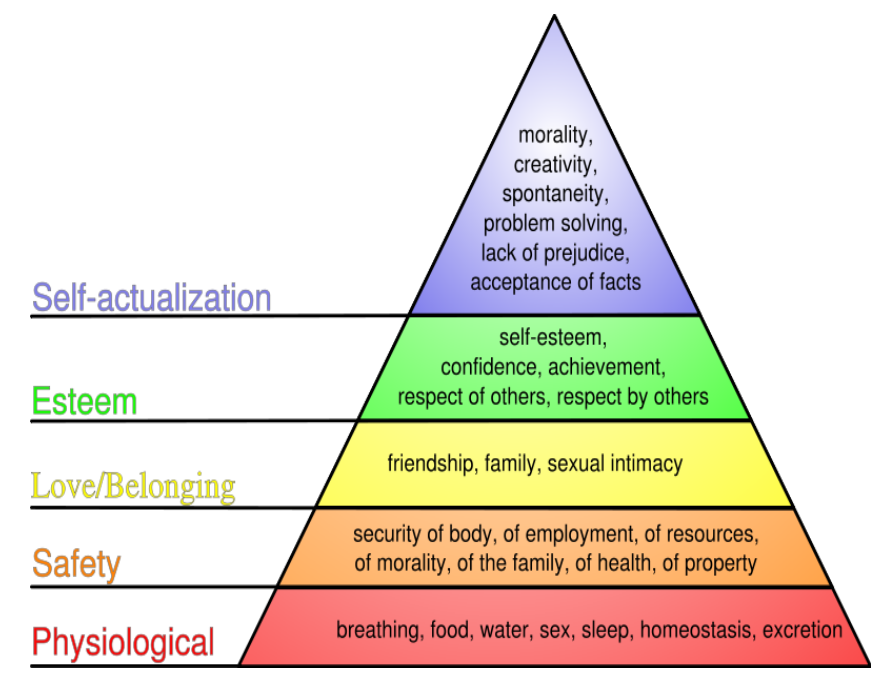

Maslow's Pyramid

According to Maslow, the pioneer of Humanistic Psychology, there is a pyramid ${ }^{8}$ and we are not a crazy-quilt confusion of motives; rather, our motives are organized in a hierarchy arranged from the most basic to the most personal and advanced. Lack of one of hierarchy's stages (Physiological, Safety, Love and Belonging, Self-esteem, Self-actualization) may cause stress and a person may experience fear as a result of this. Without satisfying the first stage (physiological), the person cannot pass to the next one.

Each approach is very important for understanding the reasons of fear and where it comes from, however, not only phobias mean fear. When we look at the facts that the fear exists, the questions which occur in our minds are: "Is our culture affected by the fear and if the answer is "yes", in what ways does it occur?" and "Is where a concept of the "fear culture"?" To find the answers to these questions, it is better to do research/look at particular areas of a country. For example, in our country, there are seven regions and each of them has their own culture. In Turkey, there are plenty of reasons of experiencing the fear; however, the main reason is based on the cultural aspects. Even though Turkey is seemed to have "one" culture, the culture of the East and West shows huge differences. Let's look at the main two approaches such as the way children are arisen and brought up and the gender differences between men and women. In my opinion, to find the fear differences between regions, it could be a good idea to use the pyramid that is adopted from "Maslow's hierarchy" which impressed me. Every stage of the pyramid should be observed by the fears caused by the relationships with others. The basic and the most important stage of the pyramid is the "Human Stage" which is interconnected with the other four stages: Nuclear Family, School, Job and Retirement. Moreover, the connection and the level of each fear stage are different.

\footnotetext{
${ }^{8}$ Maslow's Hierarchy of Needs
} 


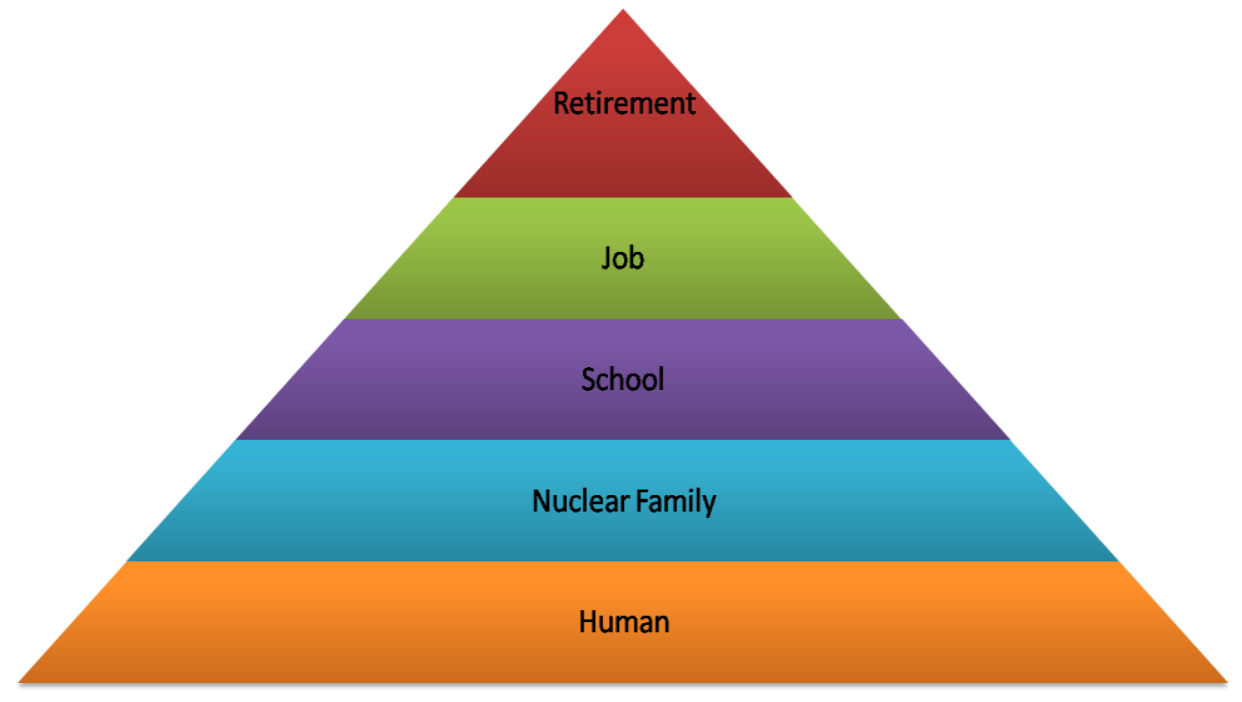

Nevin Mert's pyramid of fear' ${ }^{9}$

\section{East;}

There are some expectations from the people living in the East part of the country. There is a patriarchy, which points out that the men are leaders in the families and everything depends on them. In this culture, the women are only for fertility, feeding animals, growing up children, cooking, and nothing else. They do not have even an opportunity to exercise their right to education. Besides, there is a dogmatic system in this culture, too. The women cannot ask the reasons of the things happening around them and they cannot reject any demand coming from their husbands or fathers. All these facts are the major causes for the women of growing up with lot sorts of fear.

\section{West;}

However, the expectations from the people living in the West part of the country are absolutely different. This region allows and encourages its women to be well-educated and to have a career. The rights of men and women are approximately equal. The woman freely exercises her rights and defends them independently. Also, woman's childhood is passing not in the same way as it is passing in the Eastern culture of the country. However, causes of the fear divorces, the fact of the fear naturally exists in the West, too. As it is seen, even though the way of living is different in each region, it shows us the certain truth that the fear exists.

On the other hand, there are some researches that contain the degree of the fear on behaviour and conservation. Social psychologists and communicative experts are closely interested in this issue. According to Social Psychologists, there are some reasons why people are having a tendency to be leaded by other people. There are two statements which cause directorial reflection. One of them is to be avoided from entrepreneurial spirit. It is a kind of mood which leads people to be a passive and suppress their emotions. It causes a major problem that is being withdrawn and loosing the concept of the "self". The second statement is to shape the attitude on the mass. By using some reinforcement and punishment methods the directors lead people

\footnotetext{
${ }^{9}$ This pyramid is adopted by Maslow's Pyramid.
} 
to their own desires. These leaders choose the "right way" for their public. Here a dogmatic system takes a great place. This system represses people's "human value" and edges away from the "self". The main purpose of these two statements is to hit the people's abilities to lead themselves and suppress their conscious for taking account the power of leading. Instead of choosing literary people, the leaders prefer to supply their power in the rural regions where the number of literary people is less than in urban regions. However, it is not too easy for leaders to satisfy their "dream". They use propaganda to affect the mass. It appears with unconscious affection. With many repetitions the leaders "wash" the mass' brains and step by step approach to their aim. After these repetitions people unconsciously accept the leaders' beliefs.

Furthermore, in terms of Public Relations, there is an opinion leader who leads the mass according to his/her beliefs. The public dogmatically accept the given information. It starts from childhood. The importance of fear could be seen through the fact that $\% 90$ of fear experiences due to wrong learning and errors in it. For instance, the child can like or fear something by the suggestions of the other people (opinion leaders) even if they don't know anything about that topic ${ }^{10}$. It goes on through the life-span. The concept Lynch Mobs, which is used in Social Psychology, covers the notion "deindividuation" which means that the people having experienced this stage can feel anonymous and unidentifiable and therefore feel less concerned with what others think of their behaviour ${ }^{11}$. In addition, there is a threshold porter, too. Here, the people gradually accept the given information and the threshold porter does this in an indirect way. The news coming from "mass communication channels" are divided into two parts. The first type is that case may happen/occur at any time like traffic accidents, suicide and the second type of coming news is the cases which do not happen immediately. Before publishing this news it is passing through threshold porters and they decide what to publish. From Behaviourist Psychology aspect, Skinner's perspective ${ }^{12}$ (to teach a behaviour to a person or to an organism by applying gradually rather than wholesale; in other words, teaching a behaviour step by step), the aim of all these leaders is to influence people by using the media. The public have strongly affected by the media and it shows how the media is effective in people's behavioural changes. Moreover, the approach of Scott Peck who mentioned opinions about public relations claimed that the basis of fear is a result of laziness ${ }^{13}$. According to him, due to a nature of humanity, the fear is a common form of the laziness. Most of our fears are happening due to the thought of loosing something that belongs to us/our statue. In this case, "risk" is the effect of losing our statue, but the "fear" is being frightened of reaching a new statue and expending effort for it. As it could be understood from these expressions, fear is a feeling about the future. Think of something undesirable that will occur may cause to heart's grief. Human experiences fear due to frightening not to obtain something desirable ${ }^{14}$. In other words, fear is the natural reaction of living beings that are face to face with danger that could be visible or invisible. Psychologists evaluate this mental condition as a useful mechanism to

\footnotetext{
${ }^{10}$ Fikret Kanad, Ailede Çocuk Terbiyesi, İstanbul 1976, s. 79, 29; Russel, a.g.e., s. 79

${ }^{11}$ Benjamin B. Lahey, Psychology An Introduction, NY: McGraw- Hill, 9th Edition, page 607

${ }_{12}$ Benjamin B. Lahey, Psychology An Introduction, NY: McGraw- Hill, 9th Edition, page 15

${ }^{13}$ Peck, a.g.e., s. 285-286

${ }^{14}$ Raşit Küçük, Sevgi Medeniyeti, Ankara 1991, s. 214
} 
provide vibrant and self-defense ${ }^{15}$ and also fear is characterized as both inevitable and basic senses.

There are some opinions about the experiencing of fear in our country. One of them is Doğan CÜCELOĞLU, the writer of book "Fear Culture". He states that "If in a society the fear culture exists and also its dominant, there is neither respect to the truth nor the life of the human is precious. Moreover, this society is also going to be lack of scientific view which means that the dogmatic system leads to the society. And, the lives of people will be passing meaninglessly and with dogmatism. In addition, each person and society could impress their positive thoughts and should not forget the purpose of living". It shows that he accepts the existence of fear in the country and by publishing that book he impresses his emotions to the public. However, the most interesting aspect existed in Turkey was the usage of the sentence that recalled Plato's words ("The cowardly people could never elect the monument of victory"), said:" Country cannot be built on fear! Future is not build on fear! Democracy cannot be built on fear!" ${ }^{16}$ It shows that people who recalled that are also aware of the fear in their country. Moreover, there are still some traces of "fear culture" as we are face to face in national newspapers that is "Cumhuriyet", and as an example of being awareness of it, it was published the archives titled "Korku İmparatorluğu”(The Empire of Fear). As it is seen, not only the opinion leaders but also the public is aware in experiencing fear in our society/culture. However, the most interesting question comes to minds, if we are aware in existence fear, why we let it to continue and affect us as a country?!

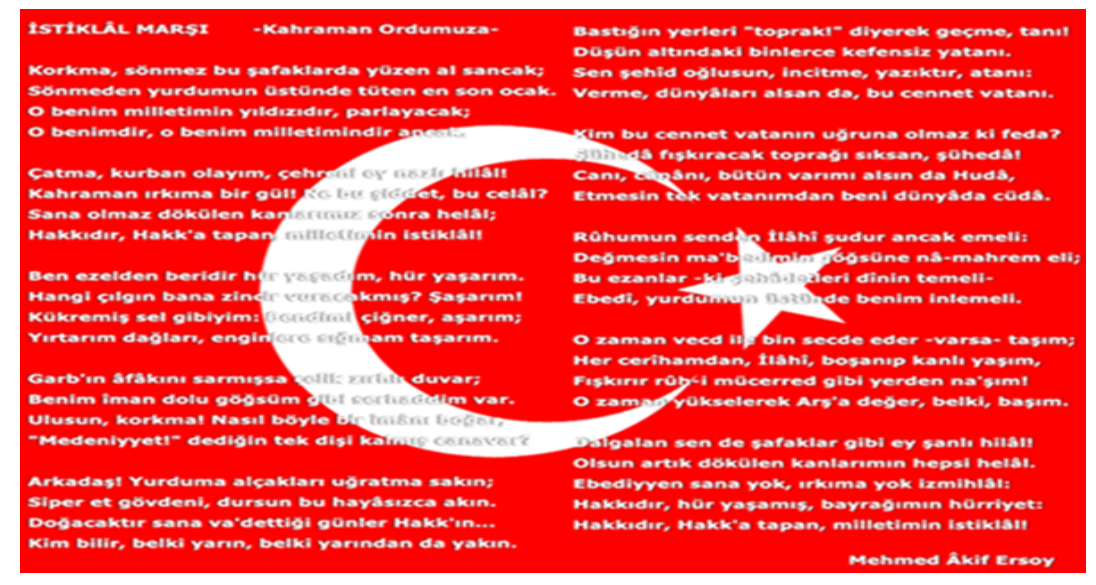

In example if we take a glance at Turkish National Athem (12 March, 1921), we find that it starts with the word "Korkma!" which means "Don't be afraid!" or "No fear!" According to the psychological approaches mentioned above, it symbolizes the economical, social and cultural perspectives of the country. The existence of the word "Korkma!" in the Turkish National Athem means that there is a fear and the message trying to be given by the National Athem is not to be afraid of anything around us. Observing this fact through the psychological approach of big five basic traits (Ashton, Lee, \& Goldberg, 2004; McCrae \& Costa, 1987, 1999; McCrae

\footnotetext{
${ }^{15}$ Mannoni, a.g.e, s. 10; Atalay Yörükoğlu, Çocuk Ruh Sağlı̆̆g, Ankara 1984, s. 220

${ }^{1} 14$ th Consultation and Evaluation speaking at the Meeting of AK Party (21/11/09)
} 
\& Terracciano, 2005), we can say that by using "Five-Factor Model of Personality" that, this "problem" could be solved. This model of personality points out that openness, extraversion, conscientiousness, agreeableness, and neuroticism are the important five-factors that could be affective in the personality of a person and as a result of the effectiveness, in the way of thinking and living could be seen some positive changes. Getting rid of especially neuroticism which includes worrying, nervous, high-strung, insecure and self-conscious will help people to cure their fears.

Taking all these facts into consideration, by describing the "fear" and approaching through psychological and socio-psychological perspectives, we tried to understand the causes and results of the fear in our country. In every moment (from birth to death) we consciously or unconsciously experience fear and it affects our life-span. By observing some perspectives, we come to a head that the East part of our country is still ruled by the despotic method, because there isn't any authority figure, thus, it has to be. Moreover, although in the East, the "death" is sanctified, in the West, the "life" is sanctified. When we look at the East, we can see that there is a fatalistic mentality. If it is needed to show the situation regrettably, a person can get frightened because of its nature and also can beat that fear by his/her joy of life and pride. In eastern side, while the fear of one is getting stronger (fear is dominating the honor), this fear can dominate the honor of the nation. In personal life, it is natural that fear can surpass other things, but if fear is dominate over honor in the East, this fear can be also felt in the Turkish National Athem. Even though we sometimes can get rid of this fear as a society, fear can surpass again. In other words, in the Turkish National Athem, there are traces of fear and this athem was accepted in 1921. Furthermore, there are still traces in our century. In daily news we can experience it, too. From past till nowadays it has existed and in the future it will also exist. As a result of our observations, we can say that our country has a fear culture. So, it proves the existence of the concept of the "fear culture" as well.

Acknowledgement: Dr. Poyraz GÜRSON, the chairperson of the department of Public Relations and Advertisement and Mr. Boğaç BERKMEN, 4th class student of the Department of Public Relations and Advertisement. 


\section{References:}

- Addington, J. E. (2001). \%100 mind power. Akaşa Yayın ve Dağıtım.

- Aydın, E. (2000). Bireysel gelişim kişisel kalite yöntemleri. Hayat Yayınları.

- Cansever, G. (1976). İçimdeki ben. Boğaziçi Üniversitesi Yayınları.

- Cottrell, S. (2005). Critical thinking skills. Printed and Bound in Chine.

- Cüceloğlu, D. (). Korku kültürü.

- Domjan, M. (2004). Essentials of conditioning and learning ( $2^{\text {nd }}$ ed.). Türk Psikologlar Derneği Yayınları, no:28.

- Dokmen, Ü. (1989). İletişim çalışmaları ve empati (20. Baskı). Sistem Yayıncılık.

- Duffy, K. G. (1998). Psychology 98/99 (28th ed.). Dushkin/ McGraw-Hill.

- Eagly, A. H., \& Chaiken, S. (1993). The psychology of attitudes. Wadsworth Cengage Learninig.

- Feldman, R. S. (1996). Understanding psychology (4 ${ }^{\text {th }}$ ed.). McGrall-Hill.

- Fulcher, J., \& Scott, J. (2003). Sociology (2nd ed.). Oxford University Press.

- Geçtan, E. (1993). Insan olmak (12. Bask1). Remzi Kitabevi.

- Keller, F. S. (2003). Psikolojinin temel dinamikleri. Yeryüzü Yayınevi.

- Lahey, B. B. (2007). Psychology an introduction, Ninth Edition, NY: McGraw-Hill.

- Marris, C. G. (2002). Understanding psychology ( $3^{\text {rd }}$ ed.). Türk Psikologlar Derneği Yayınları no:23.

- Martin, G., \& Pear, J. (2003). Behavior modification ( $7^{\text {th }}$ ed.). Upper Saddle River, NJ.

- Myers, D. G. (1995). Psychology (4 ${ }^{\text {th }}$ ed.). Worth Publishers.

- Oskay, Ü. (2000). Kitle iletişimin kültürel işlevleri, Der Yayınevi-İst.

- Papalia, D. E., Sally Wendkos Olds, \& Ruth Duskin Feldman (2007). Human Development, Tenth Edition, NY: McGraw-Hill.

- Petty, R. E., \& Cacioppo, J. T. (1996). Attitudes and persuasion. USA: Westview Press.

- Polk, T. A., \& Seiferz, C. M. (2002). Cognitive modeling. The MIT Press.

- Roediger, III. H. L., \& Capaldi, E. D., Paris, S. G., Polivy, J., \& Herman C. P. (1996). Psychology ( $4^{\text {th }}$ ed.). West Publishing Company-USA.

- Schwartz, B., Wasserman, E. A., \& Robbins, S. J. (2002). Psychology of learning and behavior ( $5^{\text {th }}$ ed.). W.W. Norton \& Company.

- Topsever, Y., \& Göregenli, M. (1994). 8. Ulusal psikoloji kongresi bilimsel çalışmaları. Türk Psikologlar Derneği Yayınları.

- Türk Psikologlar Derneği (1996). 9. Ulusal psikoloji kongresi bilimsel çalışmalart. Boğaziçi Üniversitesi.

- Wade, N. J., \& Swanston, M. T. (2001). Visual perception, an introduction. Psychology Press Ltd.

- Westen, B. (1999). Psychology; mind, brain, behavior, and culture (2 $2^{\text {nd }}$ ed.). John Wiley \& Sons.

- Westen, D. (2002). Psychology; brain, behavior, and culture ( $3^{\text {rd }}$ ed.). JW: Sons.

- Yavuzer, H. (1994). Çocuk ve suç (7.Basım). Remzi Kitabevi. 
Appendix $^{17}$

Types of phobias;

\section{Psychological conditions}

- Ablutophobia - fear of bathing, washing, or cleaning.

- Acrophobia, Altophobia - fear of heights.

- Agoraphobia - fear of places or events where escape is impossible or when help is unavailable.

- Agraphobia - fear of sexual abuse.

- Aichmophobia - fear of sharp or pointed objects.

- Algophobia - fear of pain.

- Agyrophobia - fear of crossing roads.

- Androphobia - fear of men.

- Anthropophobia - fear of people or being in a company, a form of social phobia.

- Anthophobia - fear of flowers.

- Aquaphobia, Hydrophobia - fear of water.

- Astraphobia, Astrapophobia, Brontophobia, Keraunophobia - fear of thunder, lightning and storms.

- Aviophobia, Aviatophobia - fear of flying.

- Bacillophobia, Bacteriophobia, Microbiophobia - fear of microbes and bacteria.

- Catoptrophobia - fear of mirrors or of one's own reflection.

- Chorophobia - fear of dancing.

- Cibophobia, Sitophobia - aversion to food.

- Claustrophobia - fear of confined spaces.

- Coulrophobia - fear of clowns.

- Decidophobia - fear of making decisions.

- Dental phobia, Dentophobia, Odontophobia - fear of dentists and dental procedures

- Dysmorphophobia - a phobic obsession with a real or imaginary body defect.

- Emetophobia - fear of vomiting.

- Ergasiophobia, Ergophobia - fear of work or functioning, or a surgeon's fear of operating.

- Ergophobia - fear of work or functioning.

- Erotophobia - fear of sexual love or sexual questions.

- Erythrophobia - pathological blushing.

- Gelotophobia - fear of being laughed at.

- Gephyrophobia - fear of bridges.

- Genophobia, Coitophobia - fear of sexual intercourse.

- Gerascophobia - fear of growing old or ageing.

- Gerontophobia - fear of growing old, or a hatred or fear of the elderly.

- Glossophobia - fear of speaking in public or of trying to speak.

- Gymnophobia - fear of nudity.

${ }^{17}$ Mixed citation part 
- Gynophobia - fear of women.

- Haptephobia - fear of being touched.

- Heliophobia - fear of sunlight.

- Hemophobia, Haemophobia - fear of blood.

- Hexakosioihexekontahexaphobia - fear of the number 666 .

- Hoplophobia - fear of weapons, specifically firearms.

- Ligyrophobia - fear of loud noises.

- Lipophobia - fear/avoidance of fats in food.

- Megalophobia - fear of large/oversized objects.

- Mysophobia - fear of germs, contamination or dirt.

- Necrophobia - fear of death, the dead.

- Neophobia, Cainophobia, Cainotophobia, Cenophobia, Centophobia, Kainolophobia, Kainophobia - fear of newness, novelty.

- Nomophobia - fear of being out of mobile phone contact.

- Nosophobia - fear of contracting a disease.

- Nyctophobia, Achluophobia, Lygophobia, Scotophobia - fear of darkness.

- Osmophobia, Olfactophobia - fear of smells.

- Paraskavedekatriaphobia, Paraskevidekatriaphobia, Friggatriskaidekaphobia - fear of Friday the 13th.

- Panphobia - fear of everything or constantly afraid without knowing what is causing it.

- Phasmophobia - fear of ghosts, spectres or phantasms.

- Phagophobia - fear of swallowing.

- Phobophobia - fear of having a phobia.

- Phonophobia - fear of loud sounds.

- Pyrophobia - fear of fire.

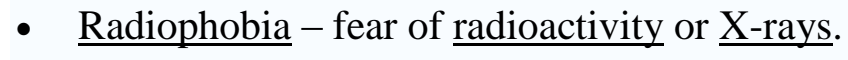

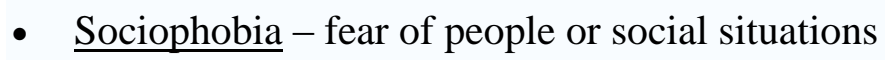

- Scopophobia - fear of being looked at or stared at.

- Somniphobia - fear of sleep.

- Spectrophobia - fear of mirrors and one's own reflections.

- Taphophobia - fear of the grave, or fear of being placed in a grave while still alive.

- Technophobia - fear of technology.

- Telephone phobia - fear or reluctance of making or taking phone calls.

- Tetraphobia - fear of the number $\underline{4}$.

- Tokophobia - fear of childbirth.

- Tomophobia - fear or anxiety of surgeries/surgical operations.

- Traumatophobia - a synonym for injury phobia, a fear of having an injury

- Triskaidekaphobia, Terdekaphobia - fear of the number 13.

- Trypanophobia, Belonephobia, Enetophobia - fear of needles or injections.

- Vaccinophobia - fear of vaccines.

- Workplace phobia - fear of the work place.

- Xenophobia - fear of strangers, foreigners, or aliens. 


\section{Animal phobias}

- Ailurophobia - fear/dislike of cats.

- Animal phobia - fear of certain animals, a category of specific phobias.

- Apiphobia, Melissophobia - fear/dislike of bees.

- Arachnophobia - fear/dislike of spiders.

- Chiroptophobia - fear/dislike of bats.

- Cynophobia - fear/dislike of dogs.

- Entomophobia - fear/dislike of insects.

- Equinophobia, Hippophobia - fear/dislike of horses.

- Herpetophobia - fear/dislike of reptiles.

- Ichthyophobia - fear/dislike of fish.

- Musophobia - fear/dislike of mice and/or rats.

- Ophidiophobia - fear/dislike of snakes.

- Ornithophobia - fear/dislike of birds.

- Scoleciphobia - fear of worms.

- Selachophobia - fear/dislike of sharks.

- Zoophobia - a generic term for animal phobias.

\section{Non-psychological conditions}

- Hydrophobia - fear of water.

- Photophobia - hypersensitivity to light causing aversion to light

- Phonophobia - hypersensitivity to sound causing aversion to sounds.

- Osmophobia - hypersensitivity to smells causing aversion to odors.

\section{Biology, chemistry}

- $\quad$ Acidophobia/Acidophobic - preference for non-acidic conditions.

- Heliophobia/Heliophobic - aversion to sunlight.

- Hydrophobia/Hydrophobic - a property of being repelled by water.

- Lipophobicity - a property of fat rejection

- Ombrophobia - avoidance of rain

- Photophobia - a negative phototaxis or phototropism response, or a tendency to stay out of the light

- Superhydrophobe - the property given to materials that are extremely difficult to get wet.

- Thermophobia - aversion to heat.

\section{Prejudices and discrimination}

- Biphobia - dislike of bisexuals.

- Chemophobia - prejudice against artificial substances in favour of 'natural' substances.

- Ephebiphobia - fear/dislike of youth.

- Gerontophobia, Gerascophobia - fear of growing old or a hatred of the elderly.

- Heterophobia - fear/dislike of heterosexuals.

- Homophobia - aversion to homosexuality or fear of homosexuals.

- Hoplophobia - aversion to firearms or firearms owners. This word has also gained a certain political notoriety as a dysphemism for "gun control advocate". 
- Judeophobia - fear/dislike of Jews.

- Lesbophobia - fear/dislike of lesbian women.

- Pedophobia, Pediophobia - fear/dislike of children.

- Psychophobia - fear/dislike of mentally ill.

- Transphobia - fear or dislike of transgender or transsexual people.

- Xenophobia - fear or dislike of foreigners.

\section{Jocular and fictional phobias}

- Aibohphobia - a joke term for the fear of palindromes, which is a palindrome itself.

- Anachrophobia - fear of temporal displacement.

- Anoraknophobia - a portmanteau of "anorak" and "arachnophobia".

- Arachibutyrophobia - fear of peanut butter sticking to the roof of the mouth.

- Hippopotomonstrosesquipedaliophobia - fear of long words.

- Nihilophobia - fear of nothingness.

- Venustraphobia - fear of beautiful women.

\section{Miscellaneous}

- $\quad$ Arachnophobia - "fear/dislike of spiders," a film

- Chromophobia - "hatred/fear of colors," a film

- Choreophobia - hatred of dance.

- Entomophobia - a genus of orchids. 